\title{
Role of Media in the Popularization of Physique Education in Higher School
}

\author{
Ke Ren \\ Department of Physical Education, Northeastern University, Shenyang, 110000, CHINA
}

Received 26 June 2017 • Revised 12 September 2017 • Accepted 30 September 2017

\begin{abstract}
With the rise and development of various media, more and more people have become the audience affected by the media. The influence of media on people's life is more and more extensive, especially for young people, the influence is more profound and lasting. At present, the multimedia technology has been applied to the vast majority of college teaching, but the application in the teaching of physical education is still in the exploration and practice stage. This paper analyzes the significance of multimedia technology applied in college sports teaching from different aspects, and it believes that the application of multimedia technology in college sports teaching not only helps to improve teaching quality and cultivate students interested in sports, but also improve teachers' occupation accomplishment. We should use the influential of media platform, to arouse public concern on the situation of college sports, to improve the students' enthusiasm for sports, and promote the college sports education and the healthy development of Chinese adolescents.
\end{abstract}

Keywords: media, physical education, higher school

\section{INTRODUCTION}

The rapid development of modern science and technology has had an unprecedented impact on sports, so that modern sports entered into a booming scientific era (Liu, 2016). With the development of science and technology, modern teaching methods are becoming more and more advanced. People can effectively improve the quality of teaching by means of modern teaching equipment (Chen, 2016). Therefore, the application of media technology to optimize teaching methods is an important feature of modern teaching methods. At present, the promotion of computer assisted instruction and network teaching makes the interactive mode of teaching diversified and provides a new development space for modern teaching methods (You, et, al., 2016). Since the traditional teaching methods are affected by many factors, how to effectively solve these problems in the actual teaching has become the key to the reform of Physical Education (Wang, 2017). When sports teacher acts and cannot display the details of the action and the action key place, it can use the film, video and television, computer demonstration and other means to deepen students' understanding of the action, to help them master the acceleration action (Bin, Wei, 2017). As a modern teaching means, multimedia teaching is a vivid and visualized teaching, which enriches the teaching methods, and its advantages are much more than the role of visual aids (Rutten, Boen, Seghers, 2012). With the rich material level, modern teaching methods have become simple and easy.

(C) Authors. Terms and conditions of Creative Commons Attribution 4.0 International (CC BY 4.0) apply. Correspondence: Ke Ren, Department of physical education, Northeastern University, Shenyang, 110000, China, 


\section{Contribution of this paper to the literature}

- By constructing the model, we get the specific role of the media in the popularization of sports education in Higher school, and avoid vague discussions.

- The multiple functions of the media are analyzed from several perspectives, and specific opinions are given from the practical point of view.

- According to the role of the media in the university sports education, the concrete method of solving the problem is given, which provides the theoretical basis for the next research.

\section{REVIEW OF CURRENT RESEARCHERS}

Physical education in higher school not only includes teaching, but also includes courses, management, teachers, students and other aspects. In order to achieve the goal of educating people, physical education needs active cooperation in these aspects (Chen, et, al., 2014). As an advanced means of education, multimedia technology can only promote the development of physical education in higher school when it is applied to all aspects of physical education (Yang, Ma, 2017). But at present, the research on media education technology and physical education in higher school mainly concentrated in sports teaching, and research on media education technology and physical education, sports management, sports teachers are scattered and superficial (Spessato, Gabbard, Valentini, 2013). For example, (Pan, 2014) believed that the positive development and application of media technology in education will play an important role in promoting the reform of physical education in higher school. The construction of excellent courses must use media education techniques, methods and means to fully embody the media education theory in curriculum management and curriculum teaching. (Wang, 2014) believes that the use of media technology can improve the effectiveness of sports work, improve the teaching and research level of sports higher school, and also improve the quality of administrative management. Through the practice of multimedia technology teaching in Wushu theory course, Huang Shan thought that it could receive good results (Shen, et, al., 2016).

After 1990s, the maturity and development of computer technology, multimedia technology and network communication technology of modern information technology, make the education get unprecedented development (Kpaza Daniel, her, Attiklem, 2015). Foreign scholars believe that popularizing modern educational technology in physical education is the inevitable result of the rapid development of modern science and technology and the development of modern education (Okada, et, al., 2015). The application of modern educational technology plays an important role in improving the quality of physical education and improving the teaching level and surface. For PE teachers, it is necessary to use modern educational technology; the Teaching Department of physical education should gradually improve the construction of the hardware and software environment of modern educational technology, make full use of multimedia and network technology to create a good learning environment for students, and help to improve students' ability to understand and analyze problems. Multimedia and network technology are the future development, but also a strong assistant in the development of modern sports education.

\section{METHODS}

Because there is no specific national policy support, sports venues and sports facilities are insufficient, development level of sporting club hotel, the level of teachers and the enthusiasm of college students to participate in sports are not high, China's college students' sports is still in decline. At the same time, it also caused some other obstacles to the healthy development of college students, such as the mental health problems of college students and the decline of resistance. It can be said that the proper sports is the key to promote the healthy development of college students. 
Table 1. The parameters of the media on the sports education in higher school

\begin{tabular}{|c|c|c|c|}
\hline Media categories & The number of people & Contact media time & Percentage of people/\% \\
\hline Television & 97 & $30 \mathrm{~min} \sim 1 \mathrm{~h}$ & 16.1 \\
\hline Newspapers & 56 & $<30$ min & 9.3 \\
\hline Magazines & 61 & $30 \mathrm{~min} \sim 1 \mathrm{~h}$ & 10.2 \\
\hline Mobile phone & 214 & $1 \mathrm{~h} \sim 3 \mathrm{~h}$ & 35.7 \\
\hline Computer & 172 & $>3 \mathrm{~h}$ & 28.7 \\
\hline
\end{tabular}

First of all, to determine the model expression formula of the two relations, the specific form of realization is as follows:

$$
Y=C+L+G+(E X-I M)
$$

In the formula (1), $Y$ is the effect of popularity of college sports education; $C$ is representative of the use of media in higher school; $L$ is acceptance of college students; $E$ is the using situation of media by college teachers; $M$ is outside interference factor; $I$ is random error in calculating value.

Secondly, through the formula 1, we can get the primary effect of media effects on college sports education, the results can scientifically predict the popularity of college sports education, and in the case of higher number of college students, it provides reliable reference for the structural adjustment of sports system and the management of sports system in higher school.

Effective data are obtained by Table 1, and the estimation result model can be obtained by bringing into formula 1:

$$
\begin{gathered}
C=\frac{1}{Y} \sum_{i=1}^{N}\left(x_{i}-n\right)\left(x_{i}-n\right)^{T} \\
Y_{2}=C+L+G+N E X+T R-T A
\end{gathered}
$$

According to formula 3 , we can get the parameters of the media on the university sports education, and these parameters can reflect the results of this relational model.

\section{RESULTS}

All kinds of media should integrate existing resources and promote the popularization and development of physical education in higher school. Under the impetus of the widespread dissemination of modern information technology, it is the most important thing to use media technology and its own advantages to popularize the sports knowledge among college teachers and students, and fundamentally solve the problem from the development of sports. The understanding of sports among college students influences their participation in sports activities to a great extent. "sports information environment" formed by all kinds of media provides an equal learning and exchange platform to the college students who are not in-depth understanding of the sports knowledge, which has had a profound and extensive impact on college students. College students can get any sports information they need through the media platform, continue to deepen their understanding of sports, but also it is conducive to college students' understanding of the nature of sports to change their old ideas, and strengthen their own sports development, to promote the healthy development of China's sports common progress of college students.

To increase the sports situation in higher school broadcast efforts by media, will inevitably cause widespread concern in the whole society, and boost the development of college students' sports. All kinds of media communication can extend the social value, also can make college students as the main body of sports population to be greatly expanded, making sports for college students, which is not only a simple outdoor sports, but also a free exchange and mutual learning opportunities. At the same time, strong media reports will inevitably arouse widespread concern about the development of sports in higher school, which will lead to the introspection of the whole society. Young people are the main population in the future to promote the development of society. Only when they have good physical and psychological qualities can they shoulder the important task of developing the 
motherland and realize the great rejuvenation dream of the Chinese nation. The widespread appeal of the media platform, while attracting social attention, can promote the rapid development of sports in higher school in China.

Using media platforms, we can expand the social influence of sports education in Higher school. Media sports can not only affect the audience's attitude towards sports, the degree of cognition, but also affect the audience's enthusiasm for sports. Especially, the youth is easy to accept new things, when using the media publicity platform, the early sports concept of China's college students will formed, to promote the rapid development of university sports in China. With its huge information capacity and immeasurable social influence, the media quickly spread the concept, connotation, behavior, spirit and influence of sports throughout China. If it wants to expand the influence of sports education in higher school, it is necessary to achieve through the media platform.

\section{DISCUSSION}

A large number of media sports on the university sports situation, is conducive to training college students' sense of identity in sports. At present, the popularity of college Students' sports knowledge is generally low, which is not conducive to the participation of college students in sports. The media can give more publicity to college students who have little knowledge of sports activities, aiming at improving the popularity of college students' sports knowledge and promoting the development of physical education in higher school. When the university students' world outlook, outlook on life and values are not stable, the content of information will have a profound impact on them. The popularization of sports related knowledge in higher school by media will inevitably deepen their understanding of sports. Media promotion in promoting the development of sports at the same time, it is also conducive to training college students' sense of identity in sports.

Media attention to sports in higher school, can enhance the attention of people from all walks of life to the status of sports in higher school. At present, from the current situation of sports activities of college students in China, the future of sports development in higher school is not optimistic. To improve this situation, we must use the influential media, the development of unique advantages and characteristics of media and China's college sports are combined to aroused widespread concern in the vast information market. When the university sports evolved into the national sports exhibition, it became a great undertaking of the whole nation to promote the development of physical education in China. The players who fight this protracted war are no longer just teachers and students of universities and colleges, and the wide participation of the whole society will inevitably push forward the great development of sports in China.

Media outreach can increase college students' enthusiasm for sports. Our college students in primary school and middle school to participate in sports consciousness is relatively weak, coupled with no corresponding national policy support, the school sports facilities and education level is limited, these factors seriously hindered the enthusiasm of our college students participate in sports. While parents only pay attention to children's learning situation, students on the concept of sports is also very vague, only the use of various media to carry out publicity and education, to make students realize the importance of physical exercise for their stable development and national development. The proper use of the media, not only can influence people's way of thinking, and even guiding the public opinion and influence the audience life, especially for the college students' sports awareness and sports knowledge popularization, it is has great influence. The media broadcasts all kinds of wonderful sports events, news, and conveys a series of national policies on sports, which can increase the students' enthusiasm for sports participation in a subtle atmosphere.

Media teaching has a certain negative impact on the health of students. Media sports resources are rich, the content is brilliant, there are a large number of timely and accurate sports information, there are many popular sports reviews, many exciting events pictures and clips. These contents are the main contents that meet the needs of students' sports appreciation in daily life. These "media fast food culture" in bringing the enjoyment to contemporary college students at the same time, but also created a number of weak physical "pseudo sports population." Such students show great interest in sports for many or individual sports, but they do not like to participate in sports in person. 
The new mode of teaching does not depend entirely on the advantages of media teaching, but on the basis of the reform of physical education mode and so on. It has a positive impact on students. The application of media education technology has brought about the condition for the reform of PE teaching, and has produced its recessive function through this new teaching mode. The evaluation of a sports teaching model requires multi - directional and multi - angle. In this paper, the evaluation of sports teaching in the media environment is not comprehensive enough, and perhaps there is still a lack of scientific. This is also the field which needs further study.

\section{CONCLUSION}

The above discussions is only a preliminary rational thinking on the scientific physical education evaluation system, and the index system is only a rough framework. This framework can only further refinement for the physical education evaluation service, so there are a lot of theoretical and practical problems need further research.

\section{REFERENCES}

Bai, H. J. (2013). Analysis of the important role of physical education service system theory in higher school. Jornal of Jam Daon N, 23(4), 78-80.

Bin, T., \& Wei, W. Y. (2017). Research on the application of computer assisted instruction in the teaching of physical education in higher school. Agro Food Industry Hi Tech, 28(1), 1533-1537.

Chen, W. J. (2016). Problems, causes and Countermeasures of social media communication in Higher Vocational Colleges. Chinese Vocational and Technical Education, 32(10), 90-93.

Chen, W., Hypnar, A. J., Mason, S. A., Zalmout, S., \& Hammond-Benett, A. (2014). Students' Daily Physical Activity Behaviors: The Role of Quality Physical Education in a Comprehensive School Physical Activity Program. Journal of Teaching in Physical Education, 33(4), 592-610.

Kpazaï, G., Daniel, M. F., \& Attiklemé, K. (2015). A Pedagogical Analysis of Critical Thinking Deployed by Health and Physical Education Teachers at the Secondary School Level. Journal of Evaluation in Clinical Practice, $3(6), 1-12$.

Liu, Y. H. (2016). On College Students' Innovation-based Entrepreneurship Education in New Media Environment. Heilongjiang Researches on Higher Education, 23(6), 94-96.

Okada, N., Amemiya, N., Fujii ,Y., et al. (2015). The Intellectual Link Between Management Research and Popularization Media: A Bibliometric Analysis of the Harvard Business Review. Academy of Management Learning \& Education, 14(1), 105-110.

Pan, Y. H. (2014). Relationships among Teachers' Self-Efficacy and Students' Motivation, Atmosphere, and Satisfaction in Physical Education. Journal of Teaching in Physical Education, 33(1), 68-92.

Rutten, C., Boen, F., \& Seghers, J. (2012). How School Social and Physical Environments Relate to Autonomous Motivation in Physical Education: The Mediating Role of Need Satisfaction. Journal of Teaching in Physical Education, 31(31), 216-230.

Shen, J., Nima, B., Fan, F., \& Zhao, L. (2016). Characteristics and Existing Problems Improvement of Public Physical Education Teaching Materials in Higher Normal Higher School. Journal of Capital University of Physical Education \& Sports, 23(2), 89-92.

Spessato, B. C., Gabbard, C., \& Valentini, N. C. (2013). The Role of Motor Competence and Body Mass Index in Children's Activity Levels in Physical Education Classes. Journal of Teaching in Physical Education, 32(2), 118-130.

Wang, H. C. (2017). Investigation and research on the participation of physical education teachers in higher school-a case study of higher school in Henan. Journal of Jiamusi Vocational Institute, 45(18), 788-790.

Wang, Y. M. (2014). Analysis of the Role of Dance Movement on the Reform of Public Physical Education Teaching in Higher school. Journal of Kaifeng Institute of Education, 41(13), 458-460.

Yang, K. H., \& Ma, Q. (2017). To Improve the Quality of Distance Education and the Simulation of Effective Resources under the Big Data. Computer Simulation, 34(4), 212-215. 
You, J., Xia, W., Chen, W. F., \& Liao, Q. (2016). Comprehensive evaluation on luminous environment of multimedia classroom in primary and middle schools. Chinese Journal of School Health, 37(3), 428-431.

Yuan, J. (2013). Analysis of lifelong physical education and sports teaching reform in higher school. Jornal of Jam Daon N, 12(3), 56-60.

\section{http://www.ejmste.com}

